\title{
SINTESIS DAN KARAKTERISASI DYE SENSITIZED SOLAR CELL (DSSC) DENGAN SENSITIZER ANTOSIANIN DARI BUNGA ROSELLA (HIBISCUS SABDARIFFA)
}

\author{
RAFIKA ANDARI * \\ ${ }^{1}$ Jurusan Teknik Elektro, Institut Teknologi Padang, 35365, Lampung Selatan, Lampung \\ * email : rafika.andari09@gmail.com
}

\begin{abstract}
Abstrak. Telah dilakukan penelitian tentang kemampuan Dye Sensitized Solar Cell pada kaca konduktif ITO dengan sensitizer dari bunga rosela (Hibiscus sabdariffa). Konstruksi sel surya yang digunakan adalah sistem sandwich. Elektroda lawan-grafit diletakkan di atas lapisan $\mathrm{TiO}_{2}$-pewarna bunga rosela dengan elektrolit terletak di antara kedua elektroda tersebut. Karakterisasi sel surya dilakukan dengan analisis serapan elektronik pada bunga rosella, Scanning Electron Microscopy (SEM), difraksi sinar X, serapan inframerah, dan pengukuran potensial sel surya. Panjang gelombang maksimum pada bunga rosela sebesar $553 \mathrm{~nm}$. Hasil analisis menggunakan Scanning Electron Microscopy (SEM) menunjukkan morfologi permukaan lapis tipis $\mathrm{TiO}_{2}$ pada perbesaran 20.000x. Pada difraktrogram lapis tipis $\mathrm{TiO}_{2}$ menunjukkan intensitas pola difraksi cukup tinggi dengan puncak utama pada $2 \theta$ yaitu $25,26^{\circ}(100) ; 47,82^{\circ}(200) ; 37,56^{\circ}(004) ; 53,66^{\circ}$ (105) dan $54,84^{\circ}$ (211) sebagai kristal anatase dengan ukuran kristal sebesar 43,76 nm. Sel-sel ini diuji dengan penyinaran menggunakan cahaya matahari dan lampu halogen 150 Watt pada jarak $30 \mathrm{~cm}$ masing-masing menghasilkan harga efisiensi sebesar 0,52\% dengan arus 0,28 mA, tegangan 238,2 $\mathrm{mV}$ serta 0,49\% dengan 0,09 $\mathrm{mA}$ dan tegangan $171,5 \mathrm{mV}$.
\end{abstract}

Kata kunci : Dye Sensitized Solar Cell (DSSC), $\mathrm{TiO}_{2}$, antocyanin, rosella

\begin{abstract}
Research on the performance of Dye Sensitized Solar Cell using ITO glass with a sensitizer of rosella flower (Hibiscus sabdariffa) has been done. The solar cell is constructed in sandwich system. A Counter electrode, graphite is placed on the layer of $\mathrm{TiO}_{2}$-rosella flower dye with the electrolyte is located between the both electrode. The characterization of solar cell has been evaluated with UV-Vis spectrometer to rosella flower, Scanning Electron Microscopy (SEM), X-ray diffraction, infrared spectroscopy, and the measurement of solar cells potential and current. Research obtained maximum wavelength of dye in the rosella flower is $553 \mathrm{~nm}$. Result of analysis used the Scanning Electron Microscopy (SEM) to show the Morphology of surface of lamella $\mathrm{TiO}_{2}$ at magnification 20.000x. Diffractogram shows the high enough intensity with main peak at $2 \theta$ is $25,26^{\circ}(100) ; 47,82^{\circ}(200) ; 37,56^{\circ}(004) ; 53,66^{\circ}$ (105) and 54,84 ${ }^{\circ}(211)$ as anatase crystals. The cells were tested by irradiation with sunlight dan halogen lamp of 150 Watt at a distance $30 \mathrm{~cm}$ for each, produces the efficiency result of $0,52 \%$ and $0,49 \%$ for currents and voltages of $0,28 \mathrm{~mA}, 238,2 \mathrm{mV}$ and $0,09 \mathrm{~mA}, 171,5 \mathrm{mV}$ respectively.
\end{abstract}

Keywords : Dye Sensitized Solar Cell (DSSC), $\mathrm{TiO}_{2}$, antocyanin, rosella

\section{Pendahuluan}

Perkembangan sistem konversi energi matahari menjadi energi listrik berlangsung melalui sistem yang disebut sebagai sel fotovoltaik. Sel surya merupakan suatu mekanisme yang bekerja berdasarkan efek fotovoltaik dimana foton dari radiasi matahari diserap kemudian dikonversikan menjadi energi listrik. Efek fotovoltaik 
sendiri adalah suatu peristiwa terciptanya muatan listrik di dalam bahan sebagai akibat penyerapan cahaya dari bahan tersebut.

Sel surya yang banyak digunakan sekarang ini adalah sel surya berbasis teknologi silikon yang merupakan hasil dari perkembangan pesat teknologi semikonduktor elektronik. Walaupun sel surya sekarang didominasi oleh bahan silikon, namun mahalnya biaya produksi silikon membuat biaya konsumsinya lebih mahal daripada sumber energi fosil. Selain itu kekurangan dari sel surya silikon adalah penggunaan bahan kimia berbahaya pada proses fabrikasinya.

Seiring dengan perkembangan teknologi, dominasi tersebut bertahap mulai tergantikan dengan hadirnya sel surya generasi terbaru, yaitu Dye-Sensitized Solar Cell (DSSC). Dye-Sensitized Solar Cell (DSSC) adalah salah satu teknologi sel surya non-konvensional yang berkembang sejalan dengan perkembangan nanoteknologi. Keunggulan dari DSSC adalah tidak memerlukan bahan dengan kemurnian tinggi sehingga biaya produksinya relatif rendah. Sejauh ini, dye yang digunakan sebagai sensitizer dapat berupa dye sintesis maupun dye alami. Walaupun DSSC komersial dengan menggunakan dye sintesis yaitu jenis ruthenium complex telah mencapai efisiensi 9,2 \%, namun ketersediaan dan harganya yang mahal membuat adanya alternatif lain pengganti $d y e$ jenis ini yaitu $d y e$ alami yang dapat diekstrak dari bagian-bagian tumbuhan seperti daun, bunga, atau buah. Dyesensitizer alami terbukti mampu memberikan efek fotovoltaik walaupun efisiensi yang dihasilkan masih jauh lebih kecil dibandingkan zat warna sintetis. Berdasarkan hal tersebut maka dilakukan penelitian menggunakan bunga rosella yang mengandung zat warna alami sebagai sumber $d y e$.

Prinsip kerja sel surya silikon adalah berdasarkan konsep semikonduktor sambungan p-n. Sel terdiri dari lapisan semikonduktor tipe-n dan tipe-p yang membentuk sambungan p-n, lapisan antirefleksi, dan substrat logam sebagai tempat mengalirnya arus dari lapisan tipe-n (elektron) dan tipe-p (hole).

Ketika sambungan disinari, foton yang mempunyai energi sama atau lebih besar dari lebar pita energi material tersebut akan menyebabkan eksitasi elektron dari pita valensi ke pita konduksi dan akan meninggalkan hole pada pita valensi. Elektron dan hole ini dapat bergerak dalam material sehingga menghasilkan pasangan elektron-hole. Apabila ditempatkan hambatan pada terminal sel surya, maka elektron dari tipe-n akan kembali ke tipe-p sehingga menyebabkan perbedaan potensial dan arus akan mengalir.

Daya listrik yang dihasilkan sel surya ketika mendapat cahaya diperoleh dari kemampuan perangkat sel surya tersebut untuk memproduksi tegangan ketika diberi beban dan arus melalui beban pada waktu yang sama. Kemampuan ini direpresentasikan dalam kurva arus-tegangan (I-V) (Gambar 1.).

Daya listrik yang dihasilkan sel surya ketika mendapat cahaya diperoleh dari kemampuan perangkat sel surya tersebut untuk memproduksi tegangan ketika diberi beban dan arus melalui beban pada waktu yang sama. Kemampuan ini direpresentasikan dalam kurva arus-tegangan (I-V) (Gambar 1.). 


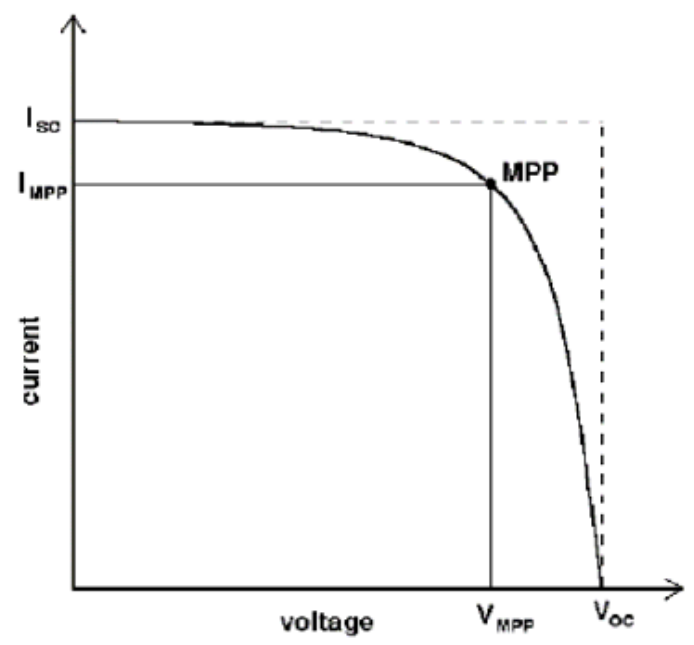

Gambar 1. Karakteristik kurva I-V pada sel surya

Ketika sel dalam kondisi short circuit, arus maksimum atau arus short circuit (ISC) dihasilkan, sedangkan pada kondisi open circuit tidak ada arus yang dapat mengalir sehingga tegangannya maksimum, disebut tegangan open-circuit (VOC). Titik pada kurva I-V yang menghasilkan arus dan tegangan maksimum disebut titik daya maksimum (MPP).

Konversi energi matahari menjadi energi listrik menghasilkan arus listrik dan tegangan. Nilai arus listrik dan tegangan dapat diukur dengan menggunakan multimeter digital. Besarnya efisiensi sel surya yang dihasilkan dapat dihitung menurut hubungan:

$$
\eta=\frac{P_{\max }}{P_{\text {in }}} x 100 \%
$$

$P_{\max }$ adalah daya maksimum yang dihasilkan oleh sel surya, dan $\mathrm{P}_{\text {in }}$ adalah daya sumber cahaya yang digunakan. $P_{\text {in }}$ dapat bersumber dari sinar matahari dengan intensitas sekitar $1000 \mathrm{~W} / \mathrm{m}^{2}$. Intensitas matahari dapat diukur menggunakan alat yang disebut luxmeter. Daya maksimum diberikan oleh hubungan:

$$
P_{\max }=V_{\max } \cdot I_{\max }=V_{O C} \cdot I_{S C} \cdot F F
$$

dengan fill factor (FF) diberikan hubungan:

$$
F F=\frac{V_{\max } \cdot I_{\max }}{V_{O C} \cdot I_{S C}}
$$

dengan $V_{\max }$ adalah tegangan maksimum yang dihasilkan sel surya dan $I_{\max }$ merupakan arus maksimum yang dihasilkan [1]. Dari nilai efisiensi inilah yang menjadi ukuran global dalam menentukan kualitas performansi suatu sel surya.

Skema kerja dari DSSC ditunjukkan pada Gambar 1. Pada dasarnya prinsip kerja dari DSSC merupakan reaksi dari transfer elektron. Proses pertama dimulai dengan terjadinya eksitasi elektron pada molekul dye akibat absorpsi foton. Proeses kedua terjadi pada elektroda negatif (anoda), yaitu pada lapisan $\mathrm{TiO}_{2}$ dimana elektron tereksitasi (D*) kemudian terinjeksi menuju pita konduksi $\left(\mathrm{E}_{\mathrm{CB}}\right) \mathrm{TiO}_{2}$ sehingga dye 
teroksidasi $\left(\mathrm{D}^{+}\right)$. Dengan adanya donor elektron oleh elektrolit $\left(\mathrm{I}^{-}\right)$maka molekul dye kembali ke keadaan awalnya (ground state) dan mencegah penangkapan kembali elektron oleh dye yang teroksidasi. Proses ketiga, setelah mencapai elektroda ITO, elektron mengalir menuju counter-elektrode yang berperan sebagai elektroda positif (katoda) melalui rangkaian eksternal. Proses selanjutnya, dengan adanya katalis pada counter-elektrode, elektron diterima oleh elektrolit sehingga hole yang terbentuk pada elektrolit $\left(\mathrm{I}_{3}{ }^{-}\right)$, akibat donor elektron pada proses sebelumnya, berekombinasi dengan elektron membentuk iodida $\left(\mathrm{I}^{-}\right)$. Proses terakhir, iodida ini digunakan untuk mendonor elektron kepada dye yang teroksidasi, sehingga terbentuk suatu siklus transport elektron. Dengan siklus ini terjadi konversi langsung dari cahaya matahari menjadi listrik.

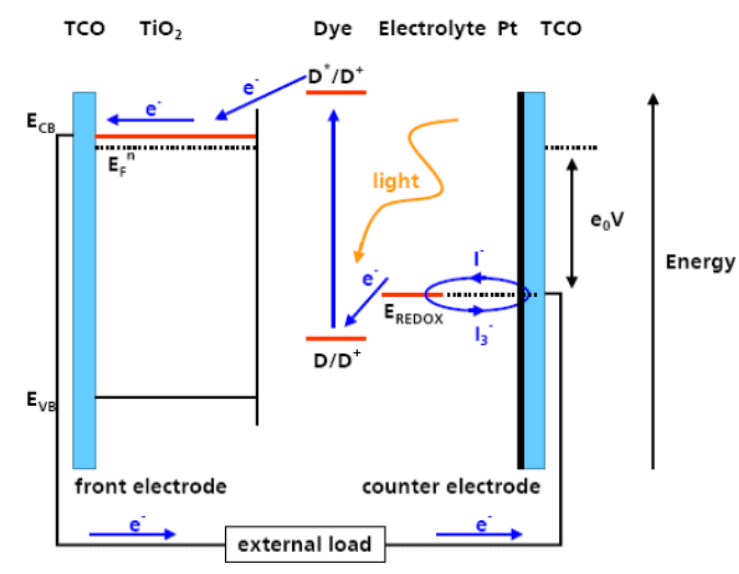

Gambar 2. Skema kerja dari DSSC [6].

\section{Metode Penelitian}

Peralatan yang digunakan dalam penelitian ini adalah gelas kimia, gelas ukur, pipet tetes, kaca konduktif (TCO) jenis ITO, magnetic stirrer, cawan petri, mortar, pensil grafit 2B, lilin bakar, pinset, oven, batang pengaduk, kertas saring, scotch tape, neraca digital, multimeter digital, potentiometer, lampu Halogen 150 watt serta luxmeter. Bahan-bahan yang digunakan dalam penelitian ini yaitu bubuk $\mathrm{TiO}_{2}$, aquades, kalium iodida (KI), iodin $\left(\mathrm{I}_{2}\right)$, etanol 95\%, asetonitril, PVA (Polivinil Alkohol), asam asetat dan kelopak bunga rosella.

Material $\mathrm{TiO}_{2}$ dideposisikan dengan teknik lapisan tebal, pada tahap awal dibuat $\mathrm{TiO}_{2}$ dalam bentuk pasta, yaitu dengan prosedur pembuatan sebagai berikut:

1. Polivinil Alkohol (PVA) ditambahkan sebanyak 3,07 gram kedalam $30 \mathrm{ml}$ aquades, kemudian diaduk hingga merata menggunakan magnetic stirrer pada temperatur $40^{\circ} \mathrm{C}$ selama 30 menit.

2. Bubuk $\mathrm{TiO}_{2}$ ditambahkan sebanyak 3,10 gram kepada suspensi tersebut sambil diaduk menggunakan magnetic stirrer pada temperatur $40^{\circ} \mathrm{C}$ sampai terbentuk pasta yang baik untuk dilapiskan. 
Derajat viskositas dari pasta untuk mendapatkan pasta yang optimal didapatkan dengan mengatur banyaknya binder dan juga bila diperlukan ditambahkan juga air pada campuran binder dan bubuk $\mathrm{TiO}_{2}$.

Kelopak bunga rosella segar sebanyak 10,2 gram digerus dengan mortar hingga halus, selanjutnya ditambahkan $25 \mathrm{ml}$ etanol 95\%, $4 \mathrm{ml}$ asam asetat, dan $21 \mathrm{ml}$ aquades (25:4:21 perbandingan volume), kemudian direndam selama 24 jam. Setelah direndam selama 24 jam, selanjutnya ekstrak dye antosianin disaring menggunakan kertas saring Whatman dan disimpan dalam botol berwarna gelap.

Sebagai sumber karbon digunakan grafit dari pensil 2B. Pensil 2B diarsir pada bagian konduktif ITO hingga merata. Kemudian kaca dibakar di atas nyala lilin dengan posisi arsiran menghadap api. Pembakaran dilakukan hingga jelaga api menutupi permukaan konduktif ITO.

Setelah masing-masing komponen DSSC berhasil dibuat kemudian dilakukan fabrikasi untuk membentuk sel surya dengan langkah-langkah sebagai berikut:

1. Pada ITO yang telah dipotong menjadi ukuran $1 \times 2 \mathrm{~cm}$ dibentuk area tempat $\mathrm{TiO}_{2}$ dideposisikan dengan bantuan Scotch tape pada bagian kaca yang konduktif sehingga terbentuk area sebesar $1 \times 1$. Scotch tape juga berfungsi sebagai pengatur ketebalan pasta $\mathrm{TiO}_{2}$.

2. Pasta $\mathrm{TiO}_{2}$ dideposisikan diatas area yang telah dibuat pada kaca konduktif dengan metoda doctor blade, yaitu dengan bantuan batang pengaduk untuk meratakan pasta. Kemudian lapisan dikeringkan selama kurang lebih 15 menit dan dibakar dalam oven listrik pada temperatur $150^{\circ} \mathrm{C}$ selama 30 menit.

3. Lapisan $\mathrm{TiO}_{2}$ kemudian direndam dalam larutan dye selama 30 menit kemudian lapisan $\mathrm{TiO}_{2}$ akan menjadi berwarna ungu. Kaca ITO kemudian dibilas dengan aquades, kemudian dibilas dengan etanol dan dikeringkan. Pada proses ini terjadi adsorpsi sianin ke permukaan $\mathrm{TiO}_{2}$, menggantikan $\mathrm{OH}^{-}$dari struktur Ti(IV) yang berkombinasi dengan proton dari grup antosianin [3].

4. Counter-elektroda karbon kemudian diletakkan diatas lapisan $\mathrm{TiO}_{2}$ dengan struktur sandwich dimana di masing-masing ujung diberi offset sebesar $0,5 \mathrm{~cm}$ untuk kontak elektrik. Kemudian agar struktur selnya mantap dijepit dengan klip pada kedua sisi.

5. Larutan elektrolit kemudian diteteskan kira-kira sebanyak 2 tetes kepada ruang antara kedua elektroda. Dan sel surya siap untuk diuji.

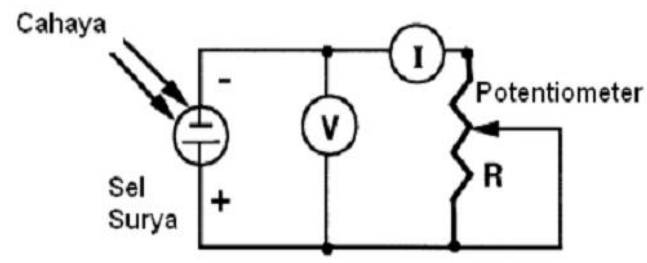

Gambar 3. Skema rangkaian listrik pengujian sel surya

Sel surya yang telah dirangkai dilakukan pengujian tegangan dan arus yang terukur dari sel surya dengan menggunakan potentiometer sebagai hambatan yang divariasikan dan dilihat perubahannya. Skema rangkaian listriknya ditunjukkan pada Gambar 3. Sumber cahaya yang digunakan yaitu cahaya matahari secara langsung dan cahaya lampu halogen 150 Watt. Jarak antara sumber cahaya lampu 
dengan sel surya adalah $30 \mathrm{~cm}$ diarahkan tegak lurus terhadap permukaan sel surya. Sedangkan karakterisasi dengan sumber cahaya matahari dilakukan pada sekitar pukul $11.00-13.00$ siang dan pada saat iluminasi cahaya matahari cerah yang diukur menggunakan luxmeter.

\section{Hasil dan Pembahasan}

asil karakterisasi elektroda $\mathrm{TiO}_{2}$ pada kaca ITO diperoleh berupa pola difraksi (difraktogram) yang terdiri dari puncak-puncak karakteristik $\mathrm{TiO}_{2}$, seperti ditunjukkan pada Gambar 4. Puncak-puncak karakteristik $\mathrm{TiO}_{2}$ sangat jelas muncul pada difraktogram dengan orientasi pada sudut $2 \theta=25,26^{\circ}$ dengan persentase $100 \%$ yang bersesuaian dengan bidang kristal (101). Puncak-puncak karakteristik

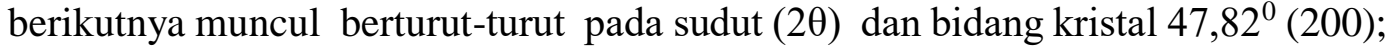
$37,56^{0}(004) ; 53,66^{0}(105) ; 54,84^{0}(211)$; dan seterusnya.

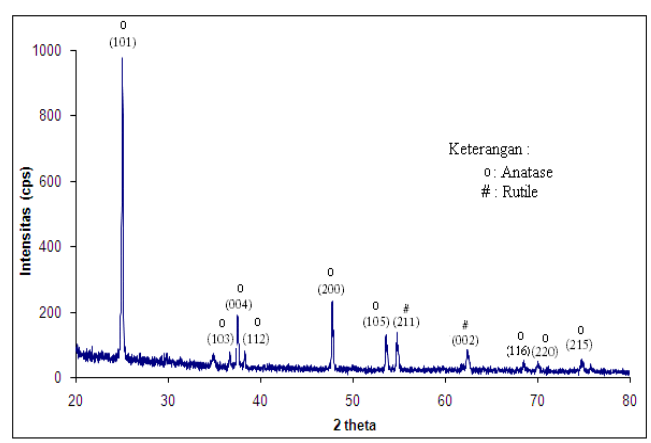

Gambar 4. Pola XRD Elektroda $\mathrm{TiO}_{2}$

Puncak-puncak $\mathrm{TiO}_{2}$ ini dominan dengan persentase terbanyak fasa kristal anatase. Dengan membandingkan hasil pengukuran dan kartu interpretasi data dapat diketahui bahwa kristal yang terbentuk adalah anatase sesuai dengan JCPDS No. 21-1272 dan rutile sesuai dengan JCPDS No. 21-1276. Terlihat juga bahwa intensitas pola difraksi sampel cukup tinggi menandakan mempunyai derajat kristalinitas yang baik.

Pola difraktogram yang diperoleh juga dapat digunakan untuk menentukan ukuran kristal $\mathrm{TiO}_{2}$ berdasarkan nilai FWHM (Full Width At Half-Maximum) pada berbagai puncak dengan menggunakan persamaan Scherrer. Dengan menggunakan persamaan Scherrer pada indeks bidang miller (101), ukuran kristal yang terhitung yaitu 43,76 nm. Ukuran kristal $\mathrm{TiO}_{2}$ sebesar 43,76 nm ini cukup jauh berbeda bila dibandingkan dengan hasil penelitian sebelumnya yang dilakukan oleh Marwati (2007) memperoleh ukuran kristal $\mathrm{TiO}_{2}$ masing-masing sebesar 17,36 nm dan 20,33 nm [2]. Dalam aplikasi sel surya $\mathrm{TiO}_{2}$ tersensitasi dye, ukuran partikel $\mathrm{TiO}_{2}$ berskala nanometer ini dapat menampung jumlah molekul dye lebih banyak karena terdapat pori yang lebih besar.

Dari hasil diatas dapat disimpulkan bahwa $\mathrm{TiO}_{2}$ yang disintesis sesuai untuk diaplikasikan dalam DSSC karena mempunyai fasa kristal anatase yang memiliki kemampuan fotoaktif yang tinggi. Selain itu derajat kristalinitas sampel ini cukup baik dilihat dari intensitas puncak difraksi yang tinggi dan tegas, dengan derajat kristalinitas yang baik maka proses difusi elektron di $\mathrm{TiO}_{2}$ akan lebih cepat sehingga proses transfer elektron untuk DSSC secara keseluruhan akan lebih tinggi dan dapat menigkatkan efisiensi sel surya. 
Karakterisasi SEM dilakukan untuk mengetahui mikrostruktur lapisan $\mathrm{TiO}_{2}$ pada substrat kaca ITO seperti pada Gambar 5. berupa morfologi permukaan lapisan $\mathrm{TiO}_{2}$. Hasil permukaan lapisan yang diperoleh memiliki struktur berpori namun partikel $\mathrm{TiO}_{2}$ belum tersebar merata di seluruh permukaan. Struktur pori yang terlihat umumnya adalah struktur pori antarpartikel sedangkan struktur pori dalam partikel tidak terlihat karena keterbatasan resolusi alat. Profil permukaan dapat diketahui namun ketebalan lapisan $\mathrm{TiO}_{2}$ tidak dapat diketahui karena keterbatasan data yang diperoleh.

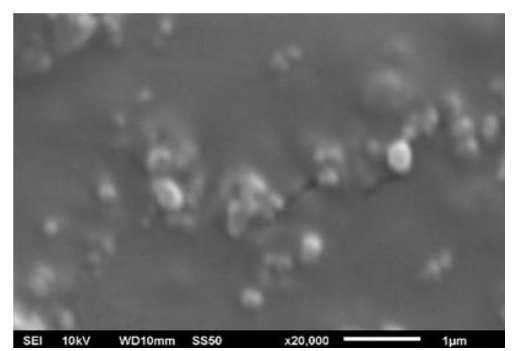

Gambar 5. Hasil SEM Sampel $\mathrm{TiO}_{2}$

Ukuran pori dalam skala nanometer tempat terserapnya molekul dye dapat terlihat meskipun tidak terlalu jelas. Hal ini disebabkan karena resolusi alat SEM yang digunakan pada penelitian ini adalah perbesaran 20.000 kali, sedangkan alat SEM yang digunakan pada penelitian Septina (2007) mempunyai resolusi yang lebih tinggi hingga 80.000 kali [3].

Hasil pengukuran diperoleh jumlah parikel elektroda $\mathrm{TiO}_{2}$ terdapat banyak pada jangkauan diameter 200-350 nm masih lebih besar dibandingkan hasil penelitian Septina (2007) yang dapat dilihat dengan ukuran pori sebesar $100 \mathrm{~nm}$ [3]. Berdasarkan hasil tabulasi di atas dibuatkan diagram sebaran ukuran partikel seperti pada Gambar 6.

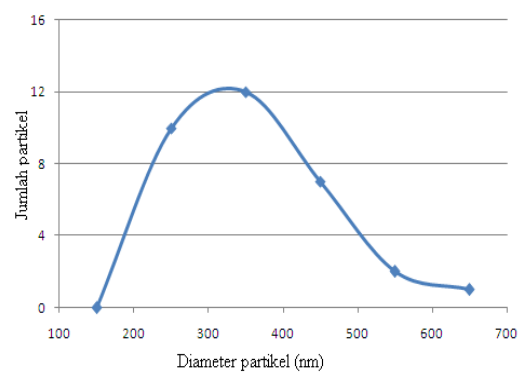

Gambar 6. Diagram sebaran ukuran partikel elektroda $\mathrm{TiO}_{2}$

Struktur nanopori dari lapisan $\mathrm{TiO}_{2}$ merupakan karakteristik penting DSSC, karena posisi dye akan berada dalam pori-pori tersebut. Morfologi lapisan berpori yang lebih banyak dapat meningkatkan jumlah molekul dye yang terserap pada permukaan partikel-partikel $\mathrm{TiO}_{2}$. Semakin banyak volume pori yang terbentuk, maka semakin luas ruang yang dapat ditempati oleh molekul dye. Hal ini menyebabkan penyerapan foton lebih mudah sehingga meningkatkan jumlah elektron terinjeksi ke permukaan $\mathrm{TiO}_{2}$ yang pada akhirnya dapat meningkatkan kemampuan sel surya. 
Setelah perendaman dalam larutan dye, lapisan $\mathrm{TiO}_{2}$ yang telah berwarna juga dilakukan pengujian karakteristik morfologinya menggunakan SEM. Hasil karakteristik lapisan ini seperti terlihat pada Gambar 7. Hasil permukaan lapisan yang diperoleh memiliki struktur berpori namun partikel $\mathrm{TiO}_{2}$ belum tersebar merata di seluruh permukaan tempat molekul dye. Untuk perendaman 30 menit memperlihatkan struktur pori yang lebih rapat. Hal ini menunjukkan bahwa dengan lama perendaman yang lebih lama ekstrak dye terserap lebih banyak daripada lama perendaman yang lebih singkat.

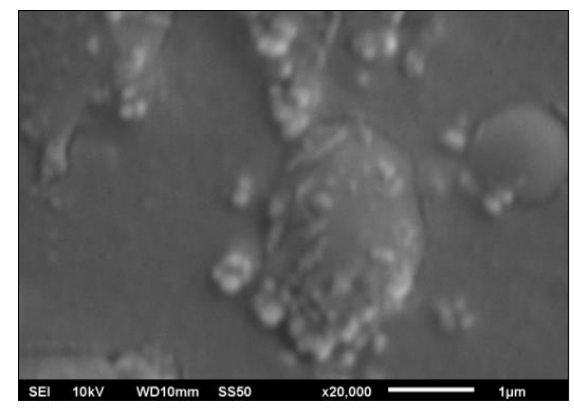

Gambar 7. Hasil SEM lapisan $\mathrm{TiO}_{2}$ setelah perendaman dalam larutan dye 30 menit

Sebelum digunakan sebagai sensitizer, ekstrak bunga rosella terlebih dahulu diuji spektrum absorpsinya dengan menggunakan instrumen spektrofotometer UV-VIS Lambda 25 Perkin Elmer dengan panjang gelombang cahaya yang digunakan antara 400-700 $\mathrm{nm}$. Spektrum absorpsi masing-masing diuji untuk dye antosianin dalam bentuk larutan sebelum dan sesudah perendaman elektroda $\mathrm{TiO}_{2}$. Hasil karakterisasi spektrum absorpsi seperti pada Gambar 8.

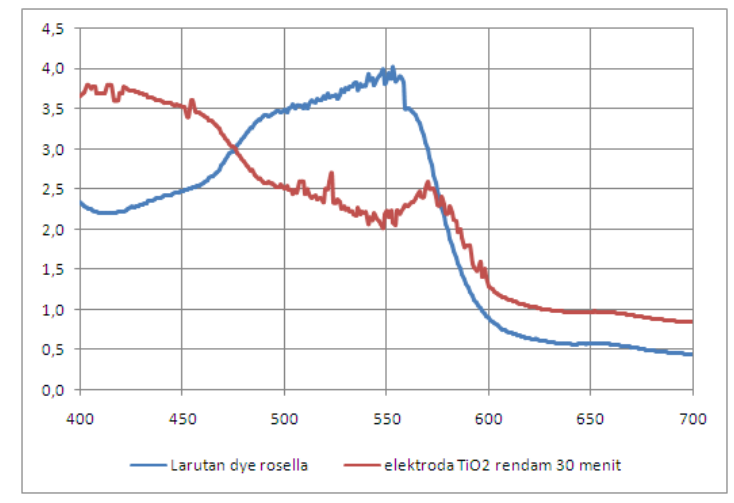

Gambar 8. Hasil spektrum absorpsi bunga rosella

Pada Gambar 8. memperlihatkan bahawa spektrum absorpsi ekstrak antosianin bunga rosella cukup lebar yaitu 450-600 nm dengan panjang gelombang maksimum $\left(\lambda_{\text {maks }}\right)$ sekitar $553 \mathrm{~nm}$. Hasil ini tidak jauh berbeda dibandingkan dengan hasil penelitian sebelumnya yang dilakukan oleh Wongcharee (2006) yang memperoleh panjang gelombang maksimum ( $\left.\lambda_{\text {maks }}\right) 520 \mathrm{~nm}$ [5]. Dengan demikian ekstrak bunga rosella sangat signifikan dan dominan menyerap cahaya tampak pada spektrum hijau (500-550 nm), hal ini bersesuaian dengan warna ekstrak yang kemerahan [4].

Pada Gambar 8. terlihat bahwa spektrum absorpsi elektroda $\mathrm{TiO}_{2}$ tersensitisasi antosianin menunjukkan pergeseran ke arah panjang gelombang lebih panjang 550$600 \mathrm{~nm}$ dengan puncak pada sekitar $570 \mathrm{~nm}$ (spektrum kuning) namun intensitasnya 
menurun. Pergeseran ini terjadi akibat perubahan warna dye setelah diserap oleh lapisan $\mathrm{TiO}_{2}$, yaitu dari warna kemerahan menjadi keunguan. Perubahan warna ini sebagai akibat terjadinya ikatan antara kromofor dye dari antosianin dengan Ti (IV) dari $\mathrm{TiO}_{2}$, dimana sebuah ion $\mathrm{OH}^{-}$dari $\mathrm{Ti}$ (IV) berikatan dengan sebuah ion $\mathrm{H}^{+}$dari dye antosianin membentuk satu molekul $\mathrm{H}_{2} \mathrm{O}$. Selain itu, muncul pula pita absorbansi pada daerah spektrum ungu (400-430 $\mathrm{nm}$ ), yang merupakan karakteristik serapan $\mathrm{TiO}_{2}$.

Pada Gambar 8. terlihat bahwa perendaman dengan waktu 30 menit menghasilkan intensitas absorbans yang lebih besar. Hal ini disebabkan karena dengan adanya waktu perendaman konsentrasi molekul antosianin yang terserap pada permukaan elektroda $\mathrm{TiO}_{2}$. Nilai absorbans ini dipengaruhi oleh kandungan antosianin pada permukaan elektroda $\mathrm{TiO}_{2}$, karena kandungan antosianin sebanding dengan cahaya yang diserap oleh sel surya.

Sel surya yang telah dikerjakan dilakukan pengujian konversi energi dengan dua sumber cahaya, yaitu cahaya matahari langsung dan cahaya lampu Halogen 150 watt. Berdasarkan hasil pengukuran nilai arus dan tegangan yang telah dibuat dalam bentuk kurva I-V, diperoleh parameter-parameter keluaran sel surya yang ditunjukkan pada Tabel 1 .

Tabel 1. Parameter-parameter sel surya yang diperoleh dengan sumber cahaya matahari

\begin{tabular}{cccc}
\hline $\begin{array}{c}\text { Karakterisasi } \\
\mathbf{I}-\mathbf{V}\end{array}$ & $\begin{array}{c}\text { Sampel } \\
\mathbf{A} \\
(\mathbf{0 , 5} \mathbf{M})\end{array}$ & $\begin{array}{c}\text { Sampel B } \\
(\mathbf{0 , 3} \mathbf{M})\end{array}$ & $\begin{array}{c}\text { Sampel } \\
\mathbf{C} \\
(\mathbf{0 , 1} \mathbf{~ M})\end{array}$ \\
\hline Vmax (mV) & 238,2 & 227,3 & 217,3 \\
Imax (mA) & 0,28 & 0,28 & 0,20 \\
Pmax (mW) & 66,69 & 63,644 & 43,46 \\
Isc (mA) & 0,3 & 0,31 & 0,27 \\
Voc (mV) & 234 & 225,6 & 217,5 \\
Fill Factor & 0,95 & 0,91 & 0,74 \\
Efisiensi (\%) & 0,52 & 0,50 & 0,34 \\
\hline
\end{tabular}

Nilai tegangan maksimum diperoleh sebesar $238,2 \mathrm{mV}$ dan arus maksimum sebesar 0,28 mA yang dihasilkan pada sampel A dengan konsentrasi elektrolit 0,5 M. Hal ini menunjukkan nilai tegangan dan arus meningkat seiring dengan meningkatnya konsentasi elektrolit. Dengan konsentrasi elektrolit yang besar pada penelitian ini mempercepat transfer elektron didalam elektroda $\mathrm{TiO}_{2}$ menuju elektroda karbon sehingga siklus di dalam sel berjalan baik yang akan menigkatkan kemampuan sel surya.

Hasil dalam penelitian ini cukup baik untuk sel surya skala laboratorium jika dibandingkan dengan hasil penelitian sebelumnya yang dilakukan oleh Septina (2007) sebesar 162,4 mV. Untuk nilai arus maksimum yang diperoleh sebesar 0,28 $\mathrm{mA}$ pada penelitian ini masih cukup bagus bila dibandingkan dengan penelitian yang dilakukan oleh Maddu (2007) menggunakan ekstrak kol merah yang memperoleh arus sebesar 5,6 $\mu \mathrm{A}$ dan Septina (2007) menggunakan ekstrak buah delima sebesar $0,07 \mathrm{~mA}[3]$. 
Nilai arus keluaran sel surya (disebut juga arus fotonik) yang kecil disebabkan oleh resistansi lapisan elektroda semikonduktor $\mathrm{TiO}_{2}$ dan elektrolit yang digunakan. Nilai resistansi yang besar ini mengakibatkan transfer elektron dari dye teroksidasi di dalam lapisan $\mathrm{TiO}_{2}$ belum berjalan baik sehingga jumlah elektron yang mengalir ke rangkaian luar menjadi kecil, akibatnya arus yang dihasilkan juga kecil. Selain itu dapat diakibatkan oleh belum optimalnya fungsi dye dalam pembangkitan dan injeksi elektron ke lapisan elektroda $\mathrm{TiO}_{2}$.

Berdasarkan nilai tegangan maksimum dan arus maksimum dapat diketahui efisiensi sel surya, yaitu $0,52 \%$. Penggunaan jenis dye yang sama ternyata menghasilkan nilai efisiensi yang berbeda. Ini dipengaruhi oleh karakteristik yang berbeda dari bunga rosella baik dari daerah tempat tumbuhnya maupun cara ekstrak bunga rosella tersebut. Selain itu, terdapat perbedaan pada substrat yang digunakan sebagai komponen pendukung DSSC dimana pada penelitian Marwati (2007) substrat yang digunakan adalah LCD [2], sedangkan penelitian ini menggunakan substrat kaca konduktif jenis ITO.

Berdasarkan hasil pengukuran nilai arus dan tegangan yang telah dibuat dalam bentuk kurva I-V, diperoleh parameter-parameter keluaran sel surya yang ditunjukkan pada Tabel 2. Hasil pengukuran menunjukkan dengan lama perendaman 30 menit, nilai efisiensi sel surya menggunakan cahaya lampu halogen 150 watt menunjukkan nilai tertinggi pada konsentrasi elektrolit 0,3 M. Hal ini menyatakan bahwa konsentrasi larutan elektrolit yang lebih besar $(0,5 \mathrm{M})$ menghasilkan efisiensi yang lebih rendah. Ini dapat terjadi kemungkinan disebabkan oleh larutan yang kurang terjaga kemurniannya akibat penggunaan untuk pengujian sampel yang bervariasi.

Tabel 2. Parameter sel surya yang diperoleh dengan sumber cahaya lampu halogen 150 watt

\begin{tabular}{cccc}
\hline $\begin{array}{c}\text { Karakterisasi } \\
\text { I-V }\end{array}$ & $\begin{array}{c}\text { Sampel } \\
\mathbf{A} \\
(\mathbf{0 , 5} \mathbf{M})\end{array}$ & $\begin{array}{c}\text { Sampel } \\
\mathbf{B}\end{array}$ & $\begin{array}{c}\text { Sampel } \\
\mathbf{0}, \mathbf{M})\end{array}$ \\
\hline $\mathbf{( 0 , 1} \mathbf{~ M})$ \\
\hline Vmax (mV) & 124,5 & 171,5 & 101,5 \\
Imax (mA) & 0,08 & 0,09 & 0,07 \\
Pmax (mW) & 11,205 & 15,435 & 7,105 \\
Isc (mA) & 0,12 & 0,10 & 0,11 \\
Voc (mV) & 125 & 174,6 & 102,3 \\
Fill Factor & 0,74 & 0,78 & 0,63 \\
Efisiensi (\%) & 0,32 & 0,49 & 0,22 \\
\hline
\end{tabular}

Nilai tegangan maksimum dengan sumber cahaya lampu halogen 150 watt yang dihasilkan adalah sebesar $171,5 \mathrm{mV}$ dan untuk nilai arus maksimum sebesar 0,09 $\mathrm{mA}$. Berdasarkan nilai tegangan maksimum dan arus maksimum dapat diketahui efisiensi sel surya, yaitu 0,49\%. Hasil ini ternyata lebih tinggi jika dibandingkan dengan penelitian Maddu (2007) yang menggunakan lampu halogen 24 watt, yaitu sebesar 0,034\% [1]. Hal ini disebabkan perbedaan intensitas lampu halogen yang digunakan lebih besar sehingga cahaya yang diserap oleh molekul $d y e$ lebih banyak dan mempercepat transfer elektron pada elektroda $\mathrm{TiO}_{2}$ yang pada akhirnya akan meningkatkan kinerja sel surya. 
Hasil pengujian menggunakan sumber cahaya lampu ini lebih rendah dibandingkan dengan menggunakan cahaya matahari. Nilai tegangan yang lebih besar dari sumber cahaya matahari disebabkan cahaya matahari mempunyai intensitas cahaya yang lebih tinggi selain itu spektrum cahaya yang dipancarkan lebih lebar. Oleh karena itu cahaya matahari merupakan sumber iluminansi yang paling efektif untuk pengujian.

\section{Kesimpulan}

Pada penelitian ini telah berhasil dilakukan pembuatan Dye-Sensitized Solar Cell (DSSC) dengn menggunakan kombinasi bahan anorganik $\mathrm{TiO}_{2}$ dengan bahan organik dye dari ekstraksi bunga rosella. Nilai efisiensi meningkat dengan meningkatnya konsentrasi elektrolit dan semakin lamanya perendaman sel dalam ekstrak dye bunga rosella, yaitu pada lama perendaman 30 menit. Untuk sumber cahaya matahari nilai efisiensi tertinggi dengan konsentrasi elektrolit $0,5 \mathrm{M}$ sebesar $0,52 \%$. Sedangkan untuk sumber cahaya lampu halogen 150 watt nilai efisiensi tertinggi pada konsentrasi elektrolit $0,3 \mathrm{M}$ sebesar 0,49\%. Karakteristikkarakteristik yang menentukan performansi sel surya diantaranya struktur, jenis dye (karakteristik absorpsi cahaya), konsentrasi larutan elektrolit dan sumber cahaya yang digunakan.

\section{Daftar Pustaka}

1. A. Maddu, Penggunaan Ekstrak Antosianin Kol Merah Sebagai Fotosentizer Pada Sel Surya $\mathrm{TiO}_{2}$ Nanokristal Tersentisasi Dye, Departemen Fisika FMIPA, Institut Pertanian Bogor: Bogor (2007).

2. Marwati, A. Retno, Penggunaan Bunga Rosela (Hibiscus sabdariffa) sebagai Zat Warna pada Dye sensitized Solar Cell (DSSC). Jurusan Kimia FMIPA ITB :Bandung.

3. W. Septina, Pembuatan Prototipe Solar Cell Murah dengan Bahan OrganikInorganik (Dye-sensitized Solar Cell), Laporan Penelitian Bidang Energi, Institut Teknologi Bandung, Bandung (2007).

4. Sukardjo, Kimia Koordinasi, PT. Rineka Cipta : Jakarta (1992).

5. K. Wongcharee et al, Dye-Sensitized Solar Cell Using Natural Dyes Extracted From Rosella and Blue Pea Flowers, Department of Chemical Engineering, Mahanakorn University of Technology, Nong Chok, Bangkok 10530, Thailand (2006).

6. R. Sastrawan, Photovoltaic Modules of Dye Solar Cells, Disertasi University of Freiburg (2006). 